\title{
THE POWER OF WOMEN \\ PATRIACHAL CULTURE IN NOVEL GADIS TANGSI by SOEPARTO BRATA AN OVERVIEW OF FEMINIST LITERARY CRITICISM
}

\author{
Oleh : \\ Laura Andri Retno Martini \\ Study Program, University of Gadjah Mada, Yogyakarta
}

\section{A. INTRODUCTION}

The global community understand the different of gender based on biological and social indicators. The biological indicators, such as sex, the reproduction function, as a given and unchangeable factor. In the other side, the social difference leads to the different attitudes of men or women. This difference is in constructed by society. In the long run, the gender message has been mixed with the given factor, and the duty of child bearing is assumed to be the duty for women only.

The gender difference, usually leads to discrimination or bias in some forms, like double standard in many living conditions, for example in law, politics, economy, morality, etc. In that situation, women have always been discriminated directly and the subject position is claimed by men. Man is the Self, the absolute subject, the first sex in the centre position, while woman, not deliberately, is posed as an object. Woman is the Other, her existence is unimportant and under the man subordinate. She is the second sex and placed at the periphery. For the society, the situation is natural as women do not take any position in the community or make decision for the family.

The community view is formed by the patriarchy system directly or indirectly. It can be through the description of women at written text, such as a novel. The process of literature birth is precondition by social culture codes of the writer. The writing is a culture product, thus it is a culture text of a specific society. As a culture text, the writing represents its society and all system surrounding.

The unjust in gender has forced all society components to care to the women destiny. In the Indonesian novel, the focus of gender problems has related to body, existence, and women relation to men. It is seen in the fact that there are many men writers that wrote about women as the central figure of their story. Suparto Brata in his novel entitled Gadis Tangsi wanted to send the message, that at the colonial time period, the Indonesian women had tried to break the shackles of sub ordination. Teyi, Raminem, and Putri Parasi are instruments for picturing how is the liberalization and how to liberate women. Suparto Brata has successfully illustrated the figures as hardworking and non compromised women.

Novel as a text actually is not neutral. It is a product of creativity and full of the ideology of the writer. The women figures in the novel is imaginer construction that bear the writer ideology. So, to dig the neutrality of the women figure in the writing, it needs a non gender bias analyses. In the other words, to analyses women problems need women perspective, as Hellwig said: read as a woman (Hellwig, 2003:10), to understand woman problems in text or novel.

Hellwig opinion similar to Showalter 's about the important to take the perspective woman as reader in the feminist literature critics. In which, the 
HUMANIKA Vol. 21 No. 1 (2015) ISSN 1412-9418

woman as a reader or read as woman and analyses as women in the story constructed by the writer in the text. Related to the text reading in the woman perspective, as a text research it is included in research with women perspective and based on women problems.

\section{B. LITERATURE}

The research is about power domination on women, in the novel entitled Gadis Tangsi. In the previous research on the same object, Haryanti (2008), Gajah Mada University, in her thesis entitled" Gender Relation in Gadis Tangsi" explained about women live in the family and community, that had been placed inferior to men. Haryanti described all character in the novel, man or woman, and shacked off the patriarchy ideology in the novel. With the same material, Noviati (2007) in her thesis at Gajah Mada University with title "The Javaness' Women Power in Gadis Tangsi of Suparto Brata work" , used feminist critics approach and discussed about man and women figures in the linguistic aspect. These works of research have to be announced to avoid redundancy and to prove the originality of the current work. From the references, none of the previous studies on Gadis Tangsi used three topics, those are: women domination on text, picture of powerful women, and resistant and struggle they have done. Thus, the current research can be categorized as new or original research.

\section{RESEARCH METHOD}

Take of some factors and background behind the birth of Gadis Tangsi novel, the FLC (Feminist Literary Critics) then is used as method for analyses. The application of FLC theory bring the benefit on methodology and praxis, that is important for viewing the women picture and struggle to reach domination in patriarchy era, in text perspective.

The feminist literary critics can be grouped in two groups: as Anglo American feminist literary critics in "images of women" and "women writer' approaches, and as French feminist literary critics or past structural (Culler, 1983: 4664). This research is trying to show the images of women that dominate in the patriarchy world. Thus, it follows Anglo American approach. Based on the theory, method used for this research is qualitative descriptive. It is done in library research, with primary source the novel Gadis Tangsi, the work of Suparto Brata. The other sources are books, papers, writings and research results that is relevant for focusing the study. The steps and procedure used in the research are: Firstly, data collection. Secondly, decide research object, that is Gadis Tangsi novel of Suparto Brata, and choose the prime topic, that is women that struggling to build domination and power over men subordination, and toward patriarchy ideology. Thirdly, data analyses, in which the FLC is then applied in this step, with images of women approach. And fourthly, made summary based on the explanation of research result.

\section{DISCUSSION}

The Gadis Tangsi is the first novel from the Suparto Brata trilogy (the second novel is Kerajaan Raminem and the third is Mahligai di Ufuk Timur) which full with spirit of women domination. Since the start, Teyi ( the sentral figure of the novel) deliberately posed as woman that indiferance in her surrounding. There is special relation between Teyi and her mother,Raminem, and between Teyi and Raden Ayu Putri Parasi. Both Raminem and Putri Parasi have a strong influence to the development of Teyi character and emotion. 
HUMANIKA Vol. 21 No. 1 (2015) ISSN 1412-9418

Dominates The Power Of Women Patriachal Culture In Novel Gadis Tangsi

By Soeparto Brata An Overview Of Feminist Literary Criticism

Laura Andri Retno Martini

There are two patriarchy cultures behind the novel development: the private and public patriarchy. The private patriarchy is about the pressure for women in the marriage system and economic hegemony of men in the family. The public patriarchy is shown in the inferiority of the women, and position of women as sexual object.

In the private patriarchy, women do not have space for life and live as their free will, since in their childhood they are doctrined by their family and community/society as domestic, and after marriage they have to follow their husband order. It means that husband overpowers the wife body, and every decision made by the husband is mostly for the husband's benefit. In this case, the wife has to take the decision as obligation to do and as dedication to her husband. In the economic activity, as husband zone, the wife thought is washed by the internalization of false understanding that women primary duty is as mother and wife, to serve her husband and to take care her children. Even though this thought seems to elevate women position, but it is actually formed to the benefit of husband or men, by which the men have unlimited space to actualize himself to be out door, to work (privilege for work), and dominate the family economy. In Gadis Tangsi novel, the two private patriarchy is represent by Keminik that underlines her position as subject in the patriarchy ideology, that is physical representation of woman in correlation with her choice. Meantime, Teyi that is struggling to free from the patriarchy binding has to prove her offend to the gender discrimination/injustice.

The public patriarchy, that are shown in the women inferiority and position as sexual object, believe that women is a creature with low intelligent, more emotionally less rational, more sensual, like to cheating, and convenient with their position. All of these are men built opinions, and they thought the women to take this same thought. However, Teyi is not described as inferior woman, but prove herself as a capable and intelligent creature. As sexual object, in the "tatapan mata' theory, Teyi is shown as a beautiful woman physically and gets the benefit of it. It better since many man has attracted to her. This pictures the men's take side to women based on the women physical beauty. Body is everything, especially the specific part of women body. The hegemony of ideology that beautiful body is best for women to live happily. The situation is represent by Suwarti, an ugly and unhappy woman, that live in society mockery.

Other than the description of private and public patriarchy as the women barrier to achieve their need as human, there are also class and community stratification, in the feudal system than blog women to gain her power. In this system, men are posed as dominant character to have power, prosperity, and dignity.

In the dignitary standard, social class in the society has affected badly to the women since the feudal concept has been the base of the patriarchy system construction. The patriarchy system applied not only to the higher class but also the lower class, and the women do not have any right to stop it. The tradition has to be accepted as obligation of women to men. To oppose it is a madness, and the society will punish socially to women that oppose the tradition. In the prosperity and power standard, the woman that is posed as object and the other, will always been the victim.

The Gadis Tangsi novel is about battle to the patriarchy culture. The women in this novel are not weak creatures that are easily to surrender. They are both the domestic and public affairs holders. Women do not have to please men and make themselves as sexual objects, but like Teyi, Putri Parasi, and Raminem, they are 
both educated and ambitious women. They have strong relation to the people surround them. With the understanding that they have power for their own bodies and about strength they owned, they try to liberate themselves from the oppression and give message and opinion to the men of their right, their opposition, and knowledge that divorce is the right of both men and women. In this case, women give a new concept and change in norms, and men attitude and mindset. This understanding is a feminist step and power to change their world and living condition is represent in Putri Parasi way to aknowledge her husband biological need. The harmony of their relation is shown in the attitude of Ndara Sarjubehi that avoid to take a concubine. Women bravery to talk, give their opinion, make choice, and avoid the endorsement, is a sign of powerful. The oppression has forced them to be straighter and stronger. That are all described in Gadis Tangsi novel. In the divorce right, the way society sees is patriarchy way of seeing that situate women as the other and as an object. The women are the wrong party, and always to be the wrong part, while the men are always the right party. Teyi, in this case, has worked with her strategy and successful to end her marriage, free herself from unhappy marriage. This represent the modern image of women, a creature that has power to dignify her own live. In the other side, the divorce of Teyi and Supardal exposes the concept that 'woman also has right to divorce her husband'.

There are two points in Gadis Tangsi novel that can be said as the background for the resurrection of the women strength to become powerful, these are education and the role of society surrounding. With sprit and ambition to progress, to have a wider view on the future, and capability to read and write, Raminem, Teyi, and Putri Parasi have exhibited themselves as women that know about their right, power, and have strategic ways to free themselves from the men oppression. They become culture knowledgeable and knowing other culture too.

The role of people surrounding can be classified as pro-feminist and contrafeminist group. The pro side has not to be women, and the contra side has not to be men, Ndara Sarjubehi, Wongsodirjo, and Raden Mas Kus Bandarkum are the profeminists and involved in the struggle to bring power to women, while Teyi, Raminem, Putri Parasi are the pro feminist roles in all over the story.

\section{E. CONCLUSION}

The domination problem of women is a universal problem. Happens in every part of the world and society. The reasons of this problem are: first, economy disparity in man and woman; second, the oppression as the way out in the conflict, third, man authority in decision making process, and fourth, mental barrier in the women side to left the family setting. In Gadis Tangsi novel, the first and third reasons lead to men domination. Other, the communication problem has also shared to the domination since miss communication has finally put oppression as effective solution (for men).In relation to the image of women, it can not be done by women themselves. It has to be framed in man woman relationship, family, and society. Such bias might be found in the novel, but the bias has function to expose the reality of gender discrimination happened in the society.

All actions to pose women in the power are based on feminist, which try to see the positive relation between participation in production activity and women status. Feminist in this story has believed that human are born with the same rights, be man or woman, as autonomous body that leads by ratio in order to 
HUMANIKA Vol. 21 No. 1 (2015) ISSN 1412-9418

Dominates The Power Of Women Patriachal Culture In Novel Gadis Tangsi

By Soeparto Brata An Overview Of Feminist Literary Criticism

Laura Andri Retno Martini

understand the morality principal, and individual freedom and rights. This thought and believe is also based the freedom and empowerment for women, and the equalization of right between them. Thus, the research on the powerful women in Suparto Brata novel produce such implications. First, the implication that women image is equal to the man image. Second, theoretical implication which classify Suparto Brata novel as a soft deconstruction of the society, as stated by Ruthven, to change the centre of orientation in order to dig deeply women position in the society in feminist frame of thinking, not for exposing the victim but to show the role of women step in gaining power as describe by Wolf. Finally, when this research result reaches the society, it is hope to be a soft deconstruction once more, to change the society mindset about women, slowly.

\section{BIBLIOGRAPHY}

Arivia, Gadis. 2003. Filsafat Berperspektif Feminis. Jakarta: Yayasan Jurnal Perempuan.

Barker, Chris. 2005. Cultural Studies Teori \& Praktik. Yokyakarta: Kreasi Wacana.

Brata, Suprata. 2004. Gadis Tangsi. Jakarta: Kompas.

Chamamah-Soeratno, Siti. 2003. "Penelitian Sastra: Tinjaan Tentang Teori dan Metode Sebuah Pengantar" dalam Metode Penelitian Sastra (Ed. Jabrohim). Yogyakarta: Hanindita.

De Beauvoir, Simone. 1993. "The Second Sex" in Women's Studies: A Reader. Young, Pauline. Hamel Hampstead: Harvester Wheatsheaf.

Hellwig, Tineke. 1994. In the Shadow of Change: Woman in Indonesian Literature. California: Univeristy of California at Barkeley.

$$
\text { 2007. Citra Kaum }
$$

Perempuan di Hindia Belanda. Jakarta: Yayasan Obor Indonesia.
Priyatna, Aquarini dan Nori Andriyani. 2000. "Refleksi Pemikiran Feminis", dalam Perempuan Indonesia dalam Masyarakat yang Tengah Berubah. Jakarta: Program Studi Kajian Wanita Program Pasca Sarjana Universitas Indonesia.

Ruthven, K.K. 1990. Feminist Literary Studies: An Introduction. Cambridge: Cambridge University Press.

Showalter, Elaine. 1989. "Towards a Feminist Poetics" in Contemporary Literary Criticism. Davis, Robert Con (ed.). London: Longman Inc.

Sofia, Adib. 2009. Aplikasi Kritik Sastra Feminis Perempuan dalam KaryaKarya Kuntowijoyo. Yogyakarta: Citra Pustaka.

Tong, Rosemarie Putnam. 1998. Feminist Thought: a more comprehensive introduction. Second edition. St. Leonards: Allen and Unwin.

Wolf, Naomi. 1994. Fire with Fire. The New Female Power and How To Use It. New York: Vintage Books. 